\title{
KAJIAN MANAJEMEN PELAKSANAAN PEMELIHARAAN JALAN PADA RUAS JALAN OBEN BONE KAB. KUPANG NTT
}

\author{
Yosefus Conterius ${ }^{1}$ \\ ${ }^{1}$ Jurusan Teknik Sipil, Politeknik Negeri Kupang \\ *E-mail: yos.conterius@pnk.ac.id
}

\begin{abstract}
Abstrak
Konstruksi secara umum di terjemahkan sebagai segala bentuk pembuatan infrastruktur (contoh jalan, jembatan, gedung, irigasi, gedung) serta pelaksanaan pemeliharaan dan perbaikan infrastruktur. Dalam pelaksanaannya, proyek konstruksi membutuhkan suatu manajemen untuk mengolah dari bahan baku sebagai input kegiatan menjadi suatu konstruksi. Dengan kata lain, kegiatan pelaksanaan proyek konstruksi dapat diartikan sebagai suatu kegiatan sementara, yang berlangsung dalam jangka waktu terbatas dengan alokasi sumberdaya tertentu dan dimaksudkan untuk menghasilkan produk dengan kriteria-kriteria yang telah digariskan secara jelas dalam kontrak. Demikian halnya dengan proyek pemeliharaan jalan yang membutuhkan aspek manajemen proyek yang baik seperti pada ruas jalan Oben-Bone Kecamatan Nekamese Kabupaten Kupang. Jalan ini sering dilalui oleh truk-truck yang mengangkut material di pantai selatan. Selain itu juga merupakan jalan utama menuju tempat Ziarah Gua Bunda Maria yang ada di Desa Usapi. Perlu adanya pemeliharaan karena kondisi jalan lama yang sudah rusak, yang berdampak pada ketidak nyamanan yang dirasakan para pengguna jalan tersebut sehingga mengganggu arus transportasi baik jasa maupun barang. Dalam proses pelaksanaan pemeliharaan jalan Oben-Bone Kabupaten Kupang diperlukan penanganan yang baik dengan sumber daya yang memadai pula berdasarkan $5 \mathrm{M}+$ I diantaranya man (tenaga kerja), money (biaya), methods (metode), machines (peralatan), materials (bahan) market (pasar) dan Information. Hal yang perlu diperhatikan dalam pelaksanaan pemeliharaan jalan adalah penggunaan biaya dan penjadwalan waktu kerja. Penggunaan biaya harus digunakan secara efisien dan waktu kerja harus direncanakan secara efektif. Dari kedua hal tersebut akan sangat membantu dalam mencapai tujuan yaitu keberhasilan pelaksanan suatu proyek.
\end{abstract}

Kata kunci: pemeliharaan jalan, biaya.

\section{PENDAHULUAN}

Konstruksi secara umum di terjemahkan sebagai segala bentuk pembuatan infrastruktur (contoh jalan, jembatan, gedung, irigasi, gedung) serta pelaksanaan pemeliharaan dan perbaikan infrastruktur. Dalam pelaksanaannya, proyek konstruksi membutuhkan suatu manajemen untuk mengolah dari bahan baku sebagai input kegiatan menjadi suatu konstruksi. Dengan kata lain, kegiatan pelaksanaan proyek konstruksi dapat diartikan sebagai suatu kegiatan sementara, yang berlangsung dalam jangka waktu terbatas dengan alokasi sumberdaya tertentu dan dimaksudkan untuk menghasilkan produk dengan kriteria-kriteria yang telah digariskan secara jelas dalam kontrak. Sumber daya proyek konstruksi terdiri dari beberapa jenis diantaranya biaya, waktu, sumber daya manusia, material, dan juga peralatan yang digunakan dalam pelaksanaan proyek, dimana dalam mengoperasionalkan sumber daya-sumber daya tersebut perlu dilakukan dalam suatu sistem manajemen yang baik, sehingga dapat dimanfaatkan secara optimal. Unsur input dari proyek konstruksi yakni $5 \mathrm{M}+$ I diantaranya man (tenaga kerja), money (biaya), methods (metode), machines (peralatan), materials (bahan) market (pasar) dan Information, semua unsur tersebut perlu diatur sedemikian rupa sehingga proporsi unsur unsur yang menjadi kebutuhan dalam proyek konstruksi tersebut dapat tepat dalam penggunaanya dan proyek dapat berjalan secara efisien.

Demikian halnya dengan proyek pemeliharaan jalan yang membutuhkan aspek manajemen proyek yang baik seperti pada ruas jalan Oben-Bone Kecamatan Nekamese Kabupaten Kupang. Jalan ini sering dilalui oleh truk-truck yang mengangkut material di pantai selatan. Selain itu juga merupakan jalan utama menuju tempat Ziarah Gua Bunda Maria yang ada di Desa Usapi. Perlu adanya pemeliharaan karena kondisi jalan lama yang sudah rusak, yang berdampak pada ketidak nyamanan yang dirasakan para pengguna jalan tersebut sehingga mengganggu arus transportasi baik jasa maupun barang. 
Pengertian Manajemen Proyek

Menurut Terry (1987), manajemen adalah proses yang membeda-bedakan atas perencanaan, pengorganisasian, penggerakan pelaksanaan, dan pengendalian dengan memanfaatkan ilmu dan seni agar tujuan yang telah ditetapkan dapat tercapai. Menurut Iman Soeharto (1995), manajemen adalah proses merencanakan, mengorganisir, memimpin dan mengendalikan kegiatan anggota serta sumber daya yang lain untuk mencapai sasaran organisasi (perusahaan) yang telah ditentukan.

Menurut Iman Soeharto (1995), proyek adalah satu kegiatan sementara yang berlangsung dalam jangka waktu terbatas, dengan alokasi sumber daya tertentu dan dimaksudkan untuk melaksanakan tugas yang sasarannya telah digariskan dengan jelas, atau kegiatan sekali lewat, dengan waktu dan sumber daya terbatas untuk mencapai hasil akhir yang telah ditentukan, misalnya produk atau fasilitas produksi. Menurut Wulvram I. Ervianto (2004), proyek merupakan suatu kegiatan sementara yang hanya satu kali dilaksanakan dan umumnya berjangka waktu pendek.

\section{Tahap Kegiatan Dalam Proyek Konstruksi}

Kegiatan konstruksi adalah kegiatan yang harus melalui suatu proses yang panjang dan di dalamnya dijumpai banyak masalah yang harus diselesaikan. Di samping itu, di dalam kegiatan konstruksi terdapat suatu rangkaian yang berurutan dan berkaitan. Adapun beberapa tahap kegiatan dalam proyek konstruksi yaitu:

1. Tahap perencanaan

2. Tahap pengadaan/pelelangan

3. Tahap pelaksanaan

4. Tahap pemeliharaan dan persiapan penggunaan

\section{Tahap Pemeliharaan dan Persiapan Penggunaan}

Tahap pemeliharaan dan persiapan penggunaan ini bertujuan menjamin kesesuaian bangunan yang telah selesai dengan dokumen kontrak dan kinerja fasilitas sebagaimana mestinya. Selain itu, pada tahap ini juga dibuat suatu catatan mengenai konstruksi berikut petunjuk operasinya dan melatih staf dalam menggunakan fasilitas yang tersedia.

Kegiatan yang dilakukan adalah:

1. Mempersiapkan catatan pelaksana, berupa data-data selama pelaksanaan maupun gambar pelaksanaan.

2. Meneliti bangunan secara cermat dan memperbaiki kerusakan-kerusakan yang terjadi.

3. Mempersiapkan petunjuk operasional atau pelaksanaan serta pedoman pemeliharaannya.

4. Melatih staf untuk melaksanakan pemeliharaan.

\section{Network Planning}

Network planning (NWP) merupakan sebuah alat manajemen yang memungkinkan dapat lebih luas dan lengkapnya perencanaan, pelaksanaan berfungsi sebagai alat pengawasan serta pengendalian suatu proyek. Cara ini penting sekali untuk digunakan oleh mereka yang bertanggung jawab pada bidang engineering, production, marking, administration, dan research, terutama yang tidak merupakan rangkaian kegiatan yang rutin.

Pada prinsipnya suatu proyek merupakan salah satu atau kumpulan dari proyek-proyek yang dikategorikan sebagai berikut:

1. Proyek-proyek yang kompleks dengan banyak aktifitas-aktifitas yang saling bergantungan.

2. Proyek-proyek yang besar menggunakan banyak personalia, tenaga kerja, material, peralatan, waktu dan uang.

3. Proyek-proyek yang membutuhkan koordinasi antara beberapa pejabat dan departement-departement.

4. Proyek-proyek yang harus diselesaikan dalam waktu yang tepat dengan biaya yang terbatas.

\section{Bar Chart}

Bar chart adalah sekumpulan daftar kegiatan yang disusun dalam kolom arah vertikal dan kolom arah horizontal menunjukan skala waktu. Saat mulai dan akhir sebuah kegiatan dapat terlihat dengan jelas, sedangkan durasi kegiatan digambarkan oleh panjangnya diagram batang. Bar chart digunakan secara luas dalam proyek konstruksi karena sederhana, mudah dalam pembentukan dan mudah dimengerti oleh pemakainya.

Untuk menyusun Bar Chart diperlukan informasi-informasi berupa aktifitas-aktifitas yang ingin dikerjakan dan bobot prosentase pekerjaan. Informasi mengenai aktifitasaktifitas pekerjaan didapat dari gambar bestek, sedangkan yang dimaksud dengan bobot prosentase pekerjaan adalah prosentase harga satuan kegiatan terhadap harga total proyek. bobot prosentase pekerjaan diplotkan pada Bar Chart maka akan tergambar kurva yang disebut kurva $S$ yang berfungsi sebagai 
prosentase kegiatan terhadap waktu pelaksanaan.

\section{METODE PENELITIAN}

Tahapan pelaksanaan penelitian ini, dapat digambarkan dalam bentuk diagram alir

\section{Rencana Anggaran Biaya}

Membuat anggaran biaya berarti menaksir atau memperkirakan suatu barang, bangunan atau benda yang akan dibuat dengan teliti dan secermat mungkin. Penyusunan konstruksi bangunan pada dasarnya selalu disertai dengan rencana anggaran biaya (RAB). Anggaran merupakan suatu bentuk perencanaan penggunaan dana untuk melaksanakan pekerjaan dalam kurun waktu tertentu, dibuat dalam bentuk uang, jam, tenaga kerja atau dalam satuan lain.

Pihak owner membuat perhitungan atau estimasi dengan tujuan untuk mendapatkan informasi sejelas-jelasnya tentang biaya yang harus dsediakan ntuk merealisasikan proyeknya. Hasil estimasi disebut dengan OE ( Owner Estimate ) dan hasil estimasi yang dilakukan oleh konsultan perencana disebut dengan EE ( Engineer Estimate).

Pihak kontraktor membuat estimasi dengan tujuan untuk kegiatan penawaran terhadap proyek konstruksi pada saat pelelangan atau tender..

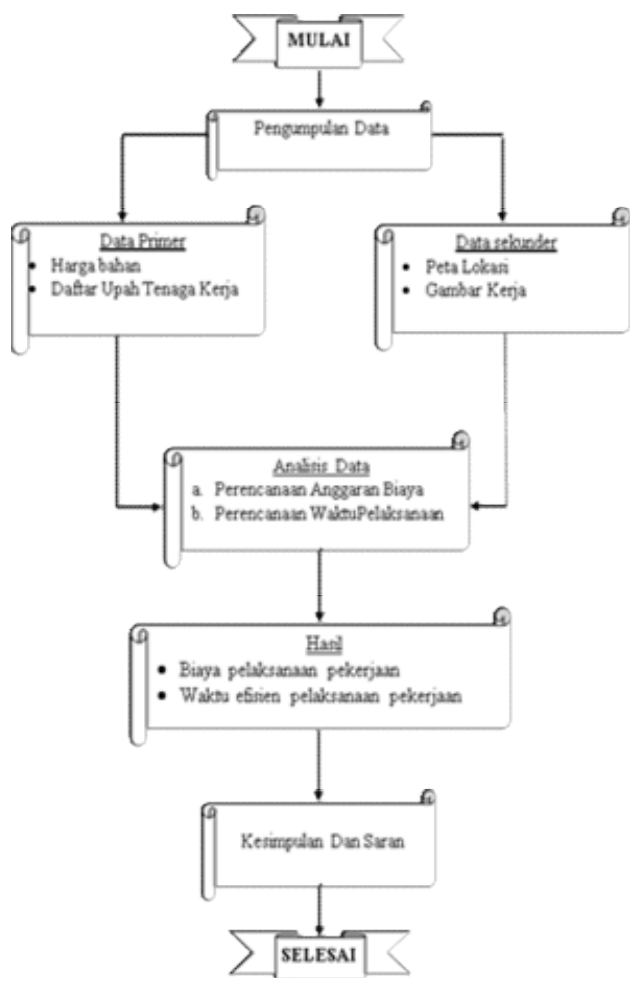

Gambar 1 Diagram Alir Penelitian. 


\begin{tabular}{|c|c|c|c|c|c|c|}
\hline mo & Unaian Kogiatarn & Kod & Seroan & Volume & $\begin{array}{c}\text { Produkai } \\
\text { hari }\end{array}$ & $\begin{array}{l}\text { Walefs } \\
\text { (hari) }\end{array}$ \\
\hline 1 & 2 & 3 & 4 & 5 & 6 & 7 \\
\hline I & Pekerjasn perampan & \multirow{4}{*}{ A } & & & & \\
\hline 1 & Prknonan pengkuran & & Ls & 1 & - & I \\
\hline 2 & Pekergas n pembersihan lokasi & & Ls & 1 & - & 1 \\
\hline 3 & Mobdisasi dan demobilisasi & & Ls & 1 & - & 1 \\
\hline II & Drainase & \multirow[b]{2}{*}{$\mathbf{B}$} & & & & \\
\hline 1 & Calian Unrak Sotokan Drainase Dan Sabran Air & & M3 & 3755 & 250 & 1 \\
\hline III & Pekerjann Tanah & $\mathbf{c}$ & & & & \\
\hline 1 & Tintunan Pithan & \multirow{3}{*}{$\mathbf{D}$} & Me & 90.06 & 250 & $\mathrm{t}$ \\
\hline IV & Per ker asan Ber burir & & & & & \\
\hline 1 & Pokerjan foveling $5 / 7$ & & $M$ & 132.69 & 156 & 1 \\
\hline $\mathbf{V}$ & Perker assen Aspal & & & & & \\
\hline 1 & Pokerjan Lapis Penotrasi racadam $5 \mathrm{Cen}$ & \multirow{3}{*}{$\mathbf{E}$} & $\mathrm{MQ}$ & 3.390 .75 & 187 & 19 \\
\hline 2 & Prime Cost (Canting Aspat) I $\mathrm{Kg}_{\mathrm{g}}$ MQ & & Letr & 3.390 .75 & 127 & 29 \\
\hline 3 & Prime Coat (Conting Aspal) $0.3 \mathrm{Kg} / \mathrm{MC}$ & & Lor & 1.156 .59 & 175 & 7 \\
\hline V1 & Strubrur & \multirow[t]{2}{*}{$\mathbf{F}$} & & & & \\
\hline I & Pasangan bats & & MB & 42.55 & 375 & 2 \\
\hline & Toeal hari & & & & & 63 \\
\hline
\end{tabular}

\section{PENUTUP}

Berdasarkan hasil penelitan diperoleh kesimpulan bahwa

1. Biaya yang dibutuhkan sebesar Rp. 159.308.000.

2. Waktu yang dibutuhkan adalah 63 hari

\section{DAFTAR PUSTAKA}

Petunjuk Pelaksanaan Pekerjaan Jalan, Ditjen Bina Marga.

Peraturan Menteri Pekerjaan Umum : 13 /PRT/M/2011 tentang tata cara pemeliharan dan penilikan jalan"

Spesifikasi Umum, Departemen Pekerjaan Umum Direktorat Jenderal Bina Marga 